\title{
Boosting the Potential of Bali as the Main Source of the Tourism Sector
}

The tourism sector is one of the sectors that has the potential to increase economic growth in Indonesia. However, in 2020, the Covid-19 pandemic caused various tourist attractions to be closed. This causes economic growth to decline. Various strategies are carried out by the government to address economic problems.

According to Tayibnapis \& Sundari (2020), The tourism market is experiencing rapid development due to lifestyle changes, the emergence of new tourist attractions, the incessant promotion of tourism, and the rapid development of attractive and affordable creative products. The whole community has to change their lifestyle because of the policies set by the government. However, these lifestyle changes have hampered the development of the tourism sector. The ban on out-of-home and the closure of tourist attractions have a major impact on economic growth.

The huge potential of tourism and the creative economy can have a big leap effect on the development of the nation's economy, especially since tourism actually grows from the bottom (Tayibnapis \& Sundari, 2020). Bali is one of the tourist sites that are in great demand by local and international people. The number of visitors who come to Bali is certainly very impactful for the Indonesian economy. According to Trip Advisor (a website for designing and booking trips based in the United States), Bali is the number one tourist destination in the world. This indicates that Bali is the main source of Indonesia's tourism sector. But in 2020, the whole world is experiencing a disaster that is the spread of coronavirus that causes various tourist attractions even a country must be closed from visits. The closure had a profound impact on the economy. There is a drastic economic downturn across the country, with the exception of Indonesia.

Collaboration between the Central and Regional Governments is needed so that the tourism sector is able to make a positive contribution to regional development, employment, retribution, foreign exchange, and others while always preserving the nature and local culture (Tayibnapis $\&$ Sundari, 2020). The role of the government is very important in boosting the potential of tourist attractions. Bali is an area that has a lot of potential as a tourist attraction. The government needs to try to make Bali more attractive to local and foreign tourists. Making policy is one of the ways that the government can develop and maintain Bali as a tourist destination, ranging from environmental management to procurement of facilities. It is certainly the main thing that can encourage the development of Bali as a tourist destination.

Pandemic is not expected to be an obstacle for the government to continue to develop the potential of Bali as a tourist destination. Despite the closure of Bali as a tourist destination, Bali remains a destination that people want to visit when the pandemic ends. The government is trying to rebuild Indonesia's declining economy by reopening various tourist destinations. The 
government can use the moment as a way to show and develop Bali's potential to the wider community.

\section{BIBLIOGRAPHY}

Kompas.com (2020, Juni 28). Upaya Memulihkan Sektor Pariwisata Indonesia Pascapandemi Covid-19. https://travel.kompas.com/read/2020/06/28/161137527/upaya-memulihkansektor-pariwisata-indonesia-pascapandemi-covid-19?page=all.

Kompas.com (2020, Agustus 2). Bali Jadi Destinasi Terbaik di Dunia Tahun 2020. https://travel.kompas.com/read/2020/08/02/130500427/bali-jadi-destinasi-terbaik-didunia-tahun-2020?page=all.

Tayibnapis, A. Z. \& Sundari, M.S. (2020). Boosting Indonesia's Tourism Sector to be Competitive. International Journal of Management \& Business Studies. 